\title{
Fertilizer Concentration Affects Growth and Nutrient Composition of Subirrigated Pansies
}

\author{
Marc van Iersel \\ Department of Horticulture, Georgia Station, The University of Georgia, 1109 \\ Experiment Street, Griffin, GA 30223-1797 \\ Additional index words. ebb and flow, $\mathrm{pH}$, electrical conductivity, EC, Viola $\times$ wittrockiana
}

\begin{abstract}
Ebb-and-flow irrigation is an economically attractive subirrigation method that reduces labor costs and eliminates runoff from greenhouses. The effects of fertilizer concentration on growth of subirrigated pansy (Viola $\times$ wittrockiana Gam.) and the leachate electrical conductivity (EC) and $\mathrm{pH}$ were quantified, using two growing media. Leachate EC increased as the EC of the fertilizer solution increased from 0.6 to $3.6 \mathrm{dS} \cdot \mathrm{m}^{-1}$ (70 to $530 \mathrm{mg} \cdot \mathrm{L}^{-1} \mathrm{~N}$ ). The leachate $\mathrm{EC}$ was fairly constant over time when the EC of the fertilizer solution was $0.6 \mathrm{dS} \cdot \mathrm{m}^{-1}$, while it increased throughout the experiment at higher fertilizer concentrations. MetroMix 300 leachate consistently had a higher EC than did MetroMix 500. Leachate pH of both growing media was similar throughout the growing season. The $\mathrm{pH}$ decreased over time and was lower with higher fertilizer concentrations. Optimal plant growth occurred with a fertilizer EC of 1.2 or $1.8 \mathrm{dS} \cdot \mathrm{m}^{-1}$, and a leachate EC between 1.5 and $4 \mathrm{dS} \cdot \mathrm{m}^{-1}$. Increasing the concentration of the fertilizer solution resulted in increased shoot tissue levels of $\mathrm{P}$ and $\mathrm{Mn}$ and decreased tissue levels of $\mathrm{K}, \mathrm{Mg}$, and $\mathrm{Na}$. The results of this study indicate that pansy is not very sensitive to the EC of the growing medium and can be grown successfully in a closed subirrigation system.
\end{abstract}

The greenhouse industry applies more fertilizer per unit area than any other agricultural system (Molitor, 1990), which can result in unacceptably high nitrogen levels $\left(>230 \mathrm{~g} \cdot \mathrm{m}^{-3}\right)$ in the soil under commercial greenhouses (McAvoy, 1994). This is a potential threat to the surface and ground water supply and growers are under increasing pressure to reduce the amount of runoff from greenhouses. This has resulted in an increasing interest in the use of closed watering systems.

Fertilizer management is more difficult in closed subirrigation systems than in overhead watering systems. With overhead watering, excess fertilizer in the growing medium can be removed by watering as water leaches from the bottom of the pots (Biernbaum, 1992). In contrast, with subirrigation salts are not leached out of the containers and often accumulate near the top of the growing medium, where evaporation occurs (Argo and Biernbaum, 1996). Because most of the root growth in subirrigated plants occurs in the bottom of the pot (Kent and Reed, 1996), the salt accumulation near the top of the growing medium is normally not detrimental to the plants. However, salts can also accumulate in the middle and bottom layers of the growing medium if the fertilizer concentration is high (Kent and

Received for publication 29 June 1998. Accepted for publication 18 Jan. 1999. I thank Larry Freeman and Kevin Calhoun for their technical assistance and Jerry Davis for his help with the statistical analysis. Mention of brand names is for information only and does not constitute an endorsement to the exclusion of other products that might also be suitable. The cost of publishing this paper was defrayed in part by the payment of page charges. Under postal regulations, this paper therefore must be hereby marked advertisement solely to indicate this fact.
Reed, 1996). Ideally, the nutrient concentration of the middle and bottom layers of the growing medium should be high enough to provide the plant with the needed nutrients, but not so high that it causes salt damage in the plants. An increase of the electrical conductivity (EC) of the bulk solution in the growing medium indicates that fertilizer is applied faster than the plants can take it up, while a low or decreasing EC suggests that there are not enough nutrients available for optimal plant growth.

The optimal fertilizer concentration in closed fertigation systems depends on the water use efficiency and nutrient requirements of the plants (Bugbee, 1995). Since water use efficiency greatly depends on environmental conditions, plant response to a range of fertilizer concentrations can be affected by greenhouse design and climatic conditions. For example, Vavrina (1996) has shown that the optimal fertilizer concentration for the production of vegetable transplants with ebb-and-flow irrigation differs in spring and fall; thus developing general recommendations for fertilizer concentrations in ebb-and-flow systems is almost impossible. Managing fertility programs using growing medium EC is more feasible, because this is a better indication of the amount of nutrients that is available to the plants than fertilizer concentration of the nutrient solution. The $\mathrm{pH}$ of the growing medium is also important because it can affect the availability of micronutrients to the plant (Bailey and Bilderback, 1997).

In subirrigation systems, most of the root growth normally occurs in the lower half of the growing medium (Kent and Reed, 1996), so $\mathrm{EC}$ and $\mathrm{pH}$ in that part of the container are most important for plant growth. The pourthrough method (Wright, 1986; Yeager et al., 1983 ) is a simple and easy method to collect leachate from the bottom part of the growing medium and can be used to quantify changes in the $\mathrm{EC}$ and $\mathrm{pH}$ of the bulk solution in the growing medium. It is a good technique for monitoring EC and $\mathrm{pH}$ of subirrigated growing media, because the results are based on that part of the medium where most of the root growth occurs.

The objectives of this study were to: 1) quantify the effect of the concentration of the fertilizer solution on $\mathrm{pH}$ and $\mathrm{EC}$ of the leachate of two different growing media, 2) quantify the effect of fertilizer concentration on the growth and tissue nutrient levels of pansies, and 3) determine the optimal range of leachate EC for pansies.

\section{Materials and Methods}

Plant material. Pansy 'Majestic Giant' was seeded in plug flats ( 288 cells/flat) filled with soilless growing medium (Redi-Earth; The Scotts Co., Marysville, Ohio) on 30 Sept. 1997. The seeds were germinated in a laboratory and subsequently transferred to a polyethylene-covered greenhouse, where the seedlings were thinned to one seedling/cell. The temperature set points for the greenhouse were $25^{\circ} \mathrm{C}$ during the day and $20{ }^{\circ} \mathrm{C}$ at night.

Treatments. Six weeks after seeding, the seedlings were transplanted into $10-\mathrm{cm}$ square pots $(510 \mathrm{~mL})$ filled with one of two soilless growing mixes (MetroMix 300 and MetroMix 500, The Scotts Co.). Media compositions and chemical properties are given in Table 1 . The pots were placed in trays on $1.2 \times 2.4-\mathrm{m}^{2} \mathrm{ebb}$ and-flow benches (MidWest GroMaster, St. Charles, Ill.). Plants were subirrigated daily with a fertilizer solution with an $\mathrm{EC}\left(\mathrm{EC}_{\text {fert }}\right)$ of $0.6,1.2,1.8,2.4,3.0$, or $3.6 \mathrm{dS} \cdot \mathrm{m}^{-1}$. Fertilizer solutions were made using a water-soluble 20N-4.4P-16.6K fertilizer (20-10-20 PeatLite Special, The Scotts Co.) and the range of EC levels corresponded to $\mathrm{N}$ concentrations of $\approx 70$ to $530 \mathrm{mg} \cdot \mathrm{L}^{-1}$. The fertilizer was selected because it is a popular water-soluble fertilizer in the bedding plant industry in the southeastern United States. It is a mixture of $\mathrm{NH}_{4} \mathrm{NO}_{3}$, $\mathrm{KH}_{2} \mathrm{PO}_{4}, \mathrm{KNO}_{3}, \mathrm{MgSO}_{4}, \mathrm{H}_{3} \mathrm{BO}_{3}, \mathrm{Cu}$-EDTA, Fe-EDTA, Mn-EDTA, Zn-EDTA, and $\mathrm{Na}_{2} \mathrm{MoO}_{4}$. It contains $7.77 \%(\mathrm{w} / \mathrm{w})$ ammoniacal $\mathrm{N}$ and $12.23 \% \mathrm{NO}_{3}^{-}-\mathrm{N}$. It is an acid-forming fertilizer, and the $\mathrm{pH}$ of the fertilizer solu-

Table 1. Composition and chemical characteristics of MetroMix 300 and MetroMix 500 soilless growing media. Both media also contain lime and a starter nutrient charge.

\begin{tabular}{|c|c|c|c|c|c|c|c|}
\hline & Sphagnum peat & Vermiculite & Perlite & Bark ash & Pine bark & \multirow[b]{2}{*}{$\mathrm{pH}$} & \multirow{2}{*}{$\begin{array}{c}\mathrm{EC} \\
\left(\mathrm{dS} \cdot \mathrm{m}^{-1}\right)\end{array}$} \\
\hline Medium & & & $(\%)$ & & & & \\
\hline MetroMix 300 & $10-25$ & $25-40$ & $5-15$ & $0-10$ & $25-45$ & 5.7 & 2.10 \\
\hline MetroMix 500 & $12-22$ & $20-35$ & 0 & $0-10$ & $40-50$ & 5.6 & 1.40 \\
\hline
\end{tabular}



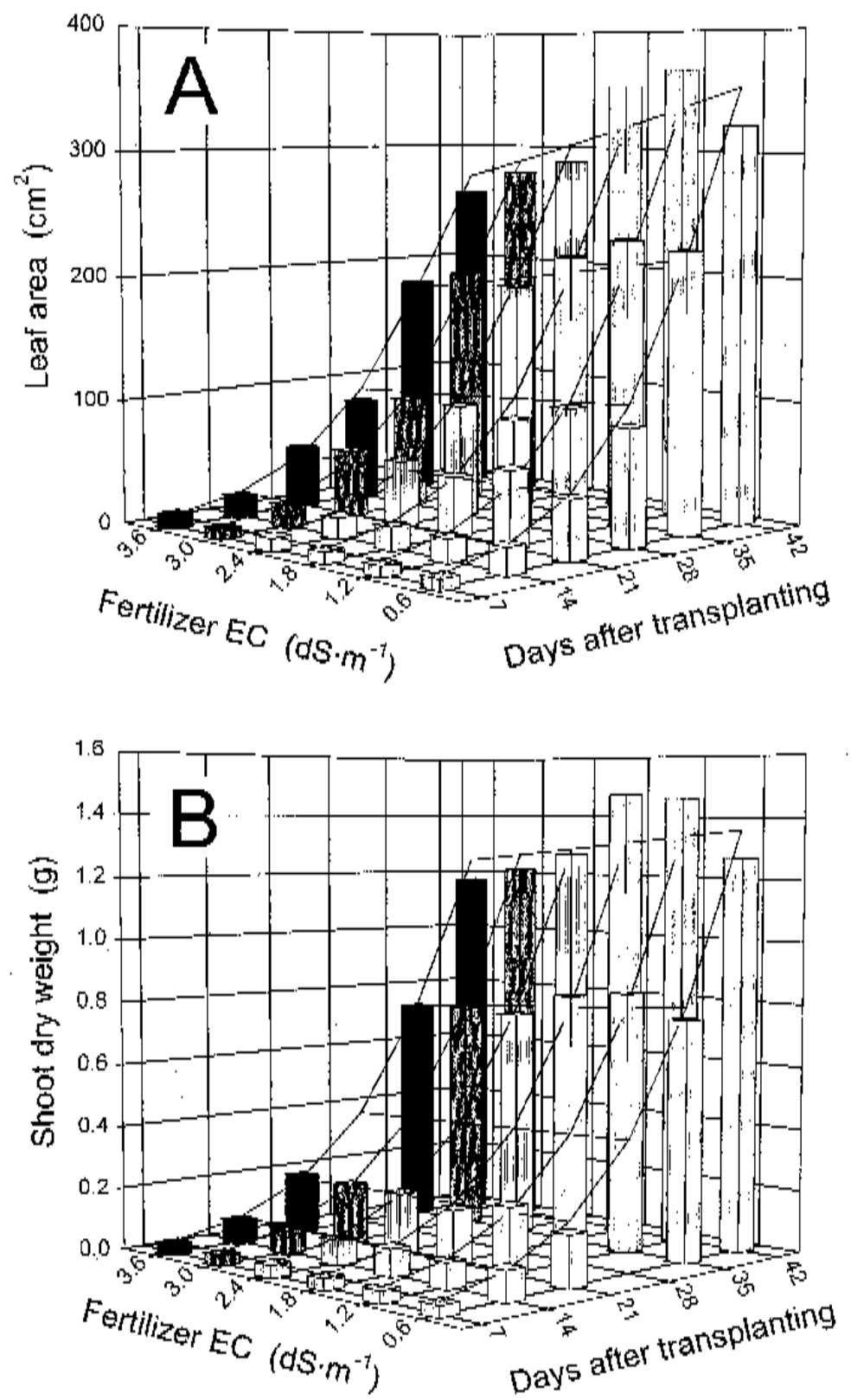

Fig. 1. The effect of fertilizer $\mathrm{EC}\left(\mathrm{EC}_{\mathrm{fer}}\right)$ on the leaf area $(\mathbf{A})$ and shoot dry weight $(\mathbf{B})$ of subirrigated pansy. Pansies were grown in 10-cm square pots and subirrigated daily with fertilizer solution. Bars are means for both growing media (12 plants per mean). Lines represent regression models [ $\ln ($ leaf area $)=1.623$ $+0.0769 \cdot \mathrm{DAT}+2.45 \cdot 10^{-3} \cdot \mathrm{DAT}^{2}-4.38 \cdot 10^{-5} \cdot \mathrm{DAT}^{3}-2.05 \cdot 10^{-3} \cdot \mathrm{EC}_{\text {fert }} \cdot \mathrm{DAT}, r^{2}=0.98, P=0.0001$; $\ln ($ shoot dry weight $)=2.898-0.03007 \cdot \mathrm{EC}_{\text {fert }}+0.1067 \cdot \mathrm{DAT}+7.78 \cdot 10^{-4} \cdot \mathrm{DAT}^{2}-2.05 \cdot 10^{-5} \cdot \mathrm{DAT}^{3}, r^{2}=$ $0.99, P=0.0001)]$.

tions was not controlled so that fertilizer effects on growing medium $\mathrm{pH}$ could be determined.

Water was pumped onto the benches using submersible pumps (NoKorode-2; Little Giant, Oklahoma City, Okla.). About 6 min were required for the pumps to fill the trays with $\approx 3$ $\mathrm{cm}$ of water, and $9 \mathrm{~min}$ for the water to drain back into the holding tanks. The fertilizer solution was stored in 210-L plastic barrels and was replenished as needed. The $\mathrm{EC}_{\text {fert }}$ was adjusted every time the barrels were refilled, but was not controlled between refills.

Data collection. Three plant shoots were harvested from every experimental unit at weekly intervals and leaf area was determined et al., 1983), EC and $\mathrm{pH}$ were always determined at 1 to $2 \mathrm{~h}$ after the last irrigation event. Data were collected until 42 DAT, when the plants started to flower and reached the stage that they would normally be sold. Entire shoot samples from the last destructive harvest were analyzed for nutrient content. Tissue $\mathrm{N}$ was determined with a CNS 2000 analyzer (LECO Corp., St. Joseph, Mich.) (Mills and Jones, 1996), while P, K, Ca, Mg, S, Al, B, Cu, Fe, $\mathrm{Mn}, \mathrm{Na}$, and $\mathrm{Zn}$ were determined by dry ashing and inductively coupled plasma spectrometry (Jones and Case, 1990).

Experimental design. The experiment was conducted on 12 ebb-and-flow benches (two replications $\times$ six fertilizer rates) with 60 plants ( 30 in each growing medium) on each bench at the start of the experiment. Thus, the experimental design was a randomized complete block with fertilizer EC as the main blocking factor and a split for the growing media. Initially, a group of 30 plants (on one bench, planted in the same growing medium) was the experimental unit, but this number decreased as plants samples were collected during the experiment. Data were analyzed by linear regression and analysis of variance (ANOVA). Shoot dry weight and leaf area were log transformed before the analyses to stabilize the variances. Polynomial regression models were developed to describe the effects of $\mathrm{EC}_{\text {fert }}$ and DAT on the $\mathrm{pH}$ and EC of the growing media, and on leaf area and shoot dry weight of the plants. The initial models included linear, quadratic, and cubic effects of both $\mathrm{EC}_{\text {fert }}$ and $\mathrm{DAT}$, and interaction terms between them $\left(\mathrm{EC}_{\text {fert }} \cdot \mathrm{DAT}, \mathrm{EC}_{\mathrm{fert}} \cdot \mathrm{DAT}^{2}, \mathrm{EC}_{\text {fert }}{ }^{2} \cdot \mathrm{DAT}\right.$, $\mathrm{EC}_{\text {fert }} \cdot \mathrm{DAT}^{3}, \mathrm{EC}_{\text {fert }}{ }^{3} \cdot \mathrm{DAT}$, and $\mathrm{EC}_{\text {fert }}{ }^{2} \cdot \mathrm{DAT}^{2}$ ). Nonsignificant $(P>0.05)$ terms were dropped from the models, until all remaining terms were significant.

\section{Results and Discussion}

Growth was similar in the two soilless media (data not shown). As expected, $\mathrm{EC}_{\text {fert }}$ did affect growth. Throughout the experiment, regression analysis indicated a decline in leaf area and shoot dry weight with increasing $\mathrm{EC}_{\text {fert }}$ (Fig. 1), suggesting that the lowest fertilizer level resulted in maximum growth. However, ANOVA indicated that at the end of the experiment, maximum leaf area occurred with an $\mathrm{EC}_{\text {fert }}$ of 0.6 to $1.8 \mathrm{dS} \cdot \mathrm{m}^{-1}$ and maximum shoot dry weight with an $\mathrm{EC}_{\text {fert }}$ of 1.2 to 2.4 $\mathrm{dS} \cdot \mathrm{m}^{-1}$. There was a small but significant decrease in plant size as $\mathrm{EC}_{\text {fert }}$ increased above $2.4 \mathrm{dS} \cdot \mathrm{m}^{-1}$. At the end of the experiment, differences in shoot dry weight and leaf area among the treatments were $<21 \%$ and $30 \%$, respectively. Although the growth (leaf area and shoot dry weight) of the plants was greatest when they were irrigated with a solution with an EC of 1.2 or $1.8 \mathrm{dS} \cdot \mathrm{m}^{-1}$, growth was acceptable when $\mathrm{EC}_{\text {fert }}$ was within 0.6 to 2.4 $\mathrm{dS} \cdot \mathrm{m}^{-1}$. The smaller size of the plants grown with an $\mathrm{EC}_{\text {fert }}$ of 3.0 or $3.6 \mathrm{dS} \cdot \mathrm{m}^{-1}$ caused a reduction in the quality of these plants, but even these plants were marketable. This indicates that pansies can be grown with a fairly wide range of fertilizer concentrations. This 

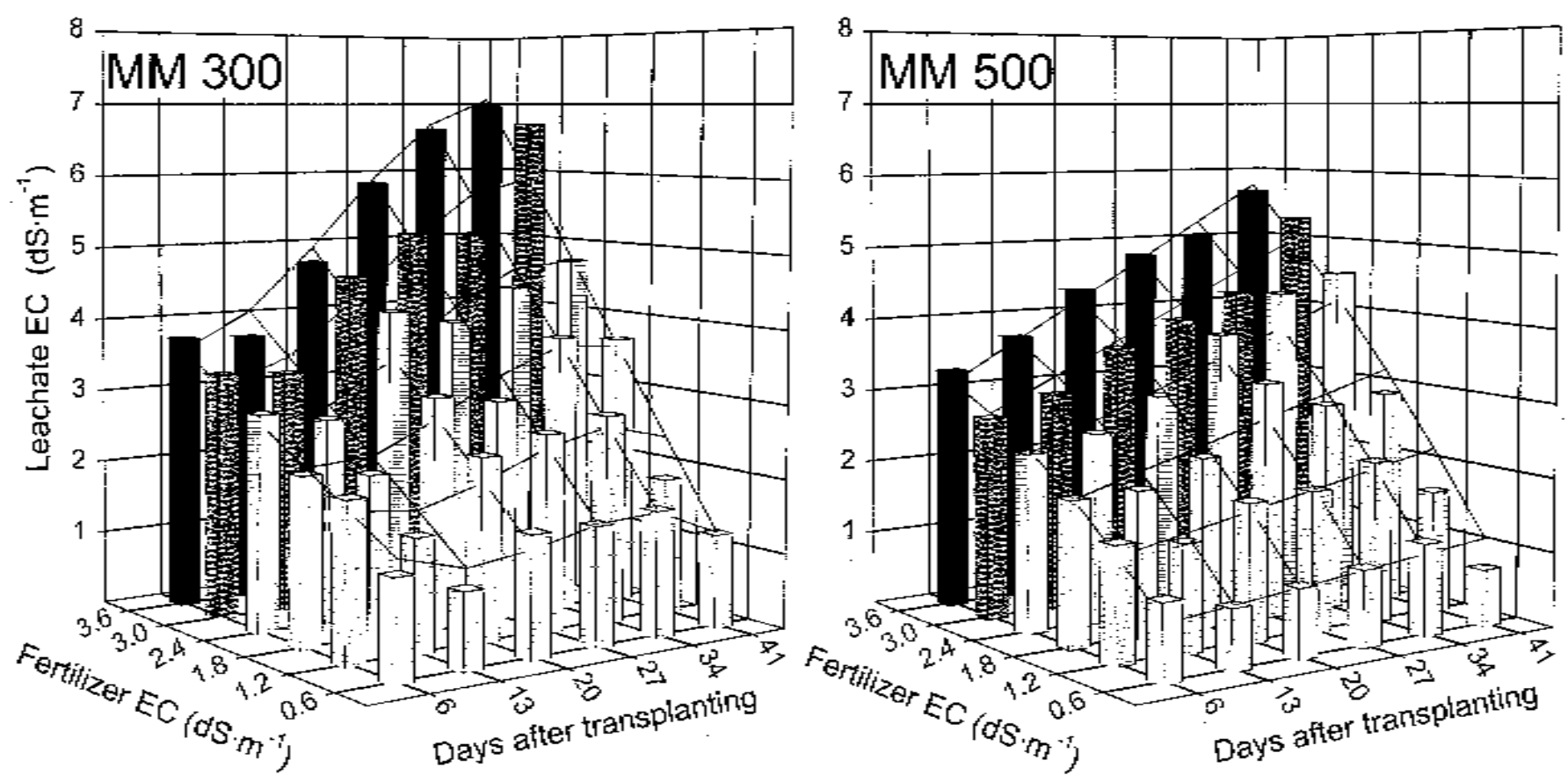

Fig. 2. The effect of fertilizer $\mathrm{EC}\left(\mathrm{EC}_{\text {fert }}\right.$ ) and time on the $\mathrm{EC}$ of leachate from two growing media [MetroMix 300 (MM300) and MetroMix 500 (MM500)]. Pansies were grown in 10-cm square pots and subirrigated daily with fertilizer solution. Bars represent means for four samples and the lines are regression models (MetroMix 300: $\mathrm{EC}_{\text {leachate }}=1.91+0.471 \cdot \mathrm{EC}_{\text {fert }}-0.184 \cdot \mathrm{DAT}-0.0358 \cdot \mathrm{DAT} \cdot \mathrm{EC}_{\text {fert }}+8.58 \cdot 10^{-3} \cdot \mathrm{DAT}^{2}-1.265 \cdot 10^{-4} \cdot \mathrm{DAT}^{3}, r^{2}=0.95, P=0.0001 ; \mathrm{MetroMix}^{2} 500$ : $\left.\mathrm{EC}_{\text {leachate }}=-0.02+1.15 \cdot \mathrm{EC}_{\text {fert }}+0.021 \cdot \mathrm{DAT} \cdot \mathrm{EC}_{\text {fert }}-0.112 \cdot \mathrm{EC}_{\text {fert }}^{2}, r^{2}=0.94, P=0.0001\right)$.

Table 2. The effect of fertilizer EC on the nutrient composition of pansy grown with daily subirrigation for $42 \mathrm{~d}$.

\begin{tabular}{|c|c|c|c|c|c|c|c|c|c|c|c|c|c|}
\hline \multirow{2}{*}{$\begin{array}{l}\text { Fertilizer EC } \\
\left(\mathrm{dS} \cdot \mathrm{m}^{-1}\right)\end{array}$} & $\mathrm{N}$ & $P$ & $\mathrm{~K}$ & $\mathrm{Ca}$ & $\mathrm{Mg}$ & $\mathrm{S}$ & $\mathrm{Al}$ & $\mathrm{B}$ & $\mathrm{Cu}$ & $\mathrm{Fe}$ & $\mathrm{Mn}$ & $\mathrm{Na}$ & $\overline{\mathrm{Zn}}$ \\
\hline & \multicolumn{6}{|c|}{$\left(\mathrm{mg} \cdot \mathrm{g}^{-1}\right)$} & \multicolumn{7}{|c|}{$\left(\mu \mathrm{g} \cdot \mathrm{g}^{-1}\right)$} \\
\hline 0.6 & 53.8 & 10.9 & 63.1 & 11.6 & 7.66 & 2.06 & 98 & 54 & 23 & 152 & 215 & 1468 & 170 \\
\hline 1.2 & 54.6 & 14.2 & 60.9 & 12.8 & 7.74 & 2.04 & 83 & 46 & 22 & 154 & 247 & 1059 & 177 \\
\hline 2.4 & 53.2 & 18.7 & 62.0 & 13.3 & 7.20 & 2.12 & 87 & 55 & 21 & 149 & 295 & 765 & 220 \\
\hline 3.0 & 55.6 & 18.4 & 56.7 & 10.8 & 6.32 & 2.05 & 71 & 58 & 19 & 135 & 294 & 770 & 202 \\
\hline 3.6 & 55.3 & 19.0 & 56.3 & 10.2 & 6.32 & 2.01 & 69 & 57 & 20 & 140 & 303 & 700 & 192 \\
\hline Significance & NS & $\mathrm{Q}^{*}$ & $\mathrm{~L}^{*}$ & NS & $\mathrm{L}^{* *}$ & NS & NS & NS & NS & NS & $\mathrm{L}^{* *}$ & $\mathrm{~L}^{* *}$ & NS \\
\hline
\end{tabular}

ss, *,** Nonsignificant or significant at $P \leq 0.05$ or 0.01 by regression analysis. $\mathrm{L}=$ linear, $\mathrm{Q}=$ quadratic.

has great practical significance, because subirrigated greenhouse crops can be grouped together if they have similar fertilizer requirements. Since pansy does not appear to be very sensitive to different $\mathrm{EC}_{\text {fert }}$ levels, it can be grown alongside many other crops.

The optimal $\mathrm{EC}_{\text {fert }}$ of 1.2 to $1.8 \mathrm{dS} \cdot \mathrm{m}^{-1}$ corresponds to a $\mathrm{N}$ concentration of 11.7 to $18.3 \mathrm{~mm}\left(164-256 \mathrm{mg} \cdot \mathrm{L}^{-1} \mathrm{~N}\right)$. This is slightly higher than the optimal $\mathrm{N}$ concentrations for subirrigated New Guinea impatiens (Impatiens hawkeri Bull.) and peace lily (Spathiphyllum Schott), which are 8 and 10 mM, respectively (Kent and Reed, 1996). When $\mathrm{EC}_{\text {fert }}$ was 1.2 or $1.8 \mathrm{dS} \cdot \mathrm{m}^{-1}$, the $\mathrm{EC}$ of the growing medium remained within 1.5 to 4 $\mathrm{dS} \cdot \mathrm{m}^{-1}$ and this appears to be the optimal range for pansies. In the treatments where the leachate EC exceeded $5 \mathrm{dS} \cdot \mathrm{m}^{-1}$, shoot dry weight and leaf area were reduced. Warncke and Krauskopf (1983) reported that a growing medium EC of 0.75 to $2 \mathrm{dS} \cdot \mathrm{m}^{-1}$ is acceptable, while 2 to 3.5 $\mathrm{dS} \cdot \mathrm{m}^{-1}$ is optimal for most greenhouse crops. Warncke and Krauskopf (1983) determined EC with the saturated media extract method, which generally gives lower readings than does the pour-through method (Yeager et al,
1983). Taking into account the difference between the two methods, the optimal range for leachate EC in this study is similar to that reported by Warncke and Krauskopf (1983).

Although there were no differences in plant growth between the two growing media, MetroMix 300 leachate consistently had a higher EC than did MetroMix 500 (Fig. 2), possibly because of its higher initial EC (Table 1). In both media, leachate EC was relatively constant when the plants were fertilized with a $0.6 \mathrm{dS} \cdot \mathrm{m}^{-1}$ solution. Leachate EC increased throughout the experiment at the higher $\mathrm{EC}_{\text {fert }}$ values and the rate rose with fertilizer concentration (Fig. 2). At the higher fertilizer concentrations, nutrients apparently were supplied faster than the plants could absorb them, resulting in an accumulation of fertilizer salts in the pots.

This inability to absorb excess nutrients is also supported by the analysis of the plants. Surprisingly, N content was high $\left(>53 \mathrm{mg} \cdot \mathrm{g}^{-1}\right)$ in all treatments and not affected by the different fertilizer concentrations (Table 2). Only tissue $\mathrm{P}$ and $\mathrm{Mn}$ levels increased significantly with increasing $\mathrm{EC}_{\text {fert }}$, while tissue $\mathrm{K}, \mathrm{Mg}$, and $\mathrm{Na}$ level decreased. Calcium and $\mathrm{Mg}$ were the only nutrients affected by the growing media. Calcium tissue concentrations generally were $2 \mathrm{mg} \cdot \mathrm{g}^{-1}$ higher in plants grown in Metro-Mix 300 than in Metro-Mix 500, while manganese levels were $40 \mu \mathrm{g} \cdot \mathrm{g}^{-1}$ lower in Metro-Mix 300 (results not shown). Tissue nutrient concentrations were high enough to support good growth, and the growth of the plants was probably not significantly affected by nutrient deficiencies or toxicities.

The different $\mathrm{EC}_{\text {fert }}$ also resulted in differences in leachate $\mathrm{pH}$ among the fertilizer treatments, but the $\mathrm{pH}$ was not affected by growing medium (Fig. 3). The pH of the leachate decreased throughout the experiment and also decreased with increasing $\mathrm{EC}_{\text {fert }}$, which would be expected with an acid-forming fertilizer. The recommended range for the $\mathrm{pH}$ of growing media for floricultural crops is 5.4 to 6.3 (Bailey and Bilderback, 1997). The leachate $\mathrm{pH}$ was within this range throughout the first 3 weeks of the growing period, but dropped to 5.2 near the end of the experiment when $\mathrm{EC}_{\text {fert }}$ was $1.2 \mathrm{dS} \cdot \mathrm{m}^{-1}$ or higher. This had no obvious effect on the growth or nutrient uptake of the plants. No visual symptoms of micronutrient toxicities or deficiencies were observed and 


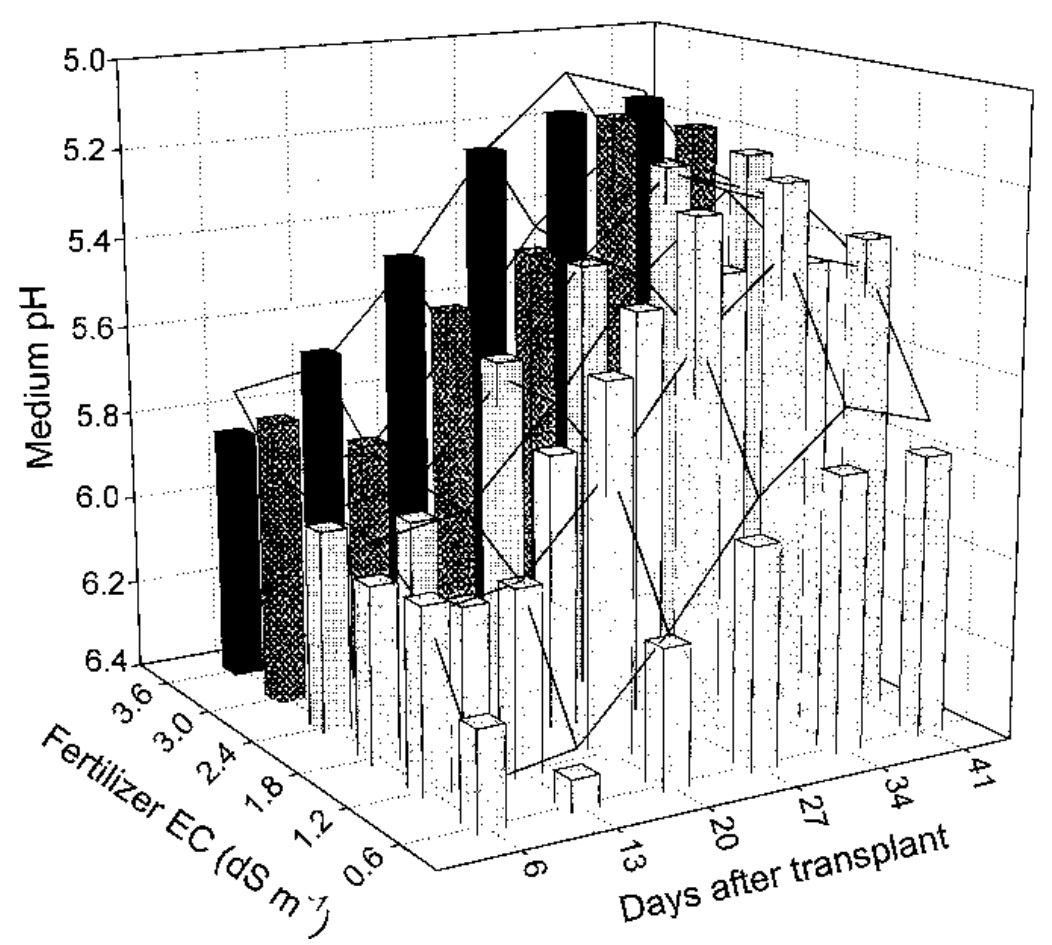

Fig. 3. The effect of fertilizer $\mathrm{EC}\left(\mathrm{EC}_{\text {fert }}\right)$ and time on the $\mathrm{pH}$ of leachate from soilless media. Pansies were grown in 10-cm square pots and subirrigated daily with fertilizer solution. Bars are means for two growing media and two replications (eight total samples) and the lines represent a regression model $(\mathrm{pH}$ $=6.69-1.29 \cdot \mathrm{EC}_{\text {fert }}+0.059 \cdot \mathrm{DAT}+0.56 \cdot \mathrm{EC}_{\text {fert }}{ }^{2}-4.33 \cdot 10^{-3} \cdot \mathrm{DAT}^{2}-0.081 \cdot \mathrm{EC}_{\text {fert }}{ }^{3}+6.46 \cdot 10^{-5} \cdot \mathrm{DAT}^{3}, r^{2}$ $=0.61, P=0.0001)$. Note that increasing bar height indicates increasing acidity and decreasing $\mathrm{pH}$

tissue levels of all nutrients were adequate at the end of the experiment (Table 2).

\section{Conclusions}

Pansies can be successfully produced in ebb-and-flow systems if the leachate EC is maintained between 1.5 and $4 \mathrm{dS} \cdot \mathrm{m}^{-1}$. Maximum growth of the plants occurred with an $\mathrm{EC}_{\text {fert }}$ of 1.2 or $1.8 \mathrm{dS} \cdot \mathrm{m}^{-1}\left(164\right.$ to $256 \mathrm{mg} \cdot \mathrm{L}^{-1}$ $\mathrm{N})$. Daily subirrigation with solutions with an $\mathrm{EC}_{\text {fert }}$ higher than $0.6 \mathrm{dS} \cdot \mathrm{m}^{-1}$ increased the EC of the growing medium throughout the growing period. MetroMix 300 leachate consis-

\section{Literature Cited}

Argo, W.R. and J.A. Biernbaum. 1996. Availability and persistence of macronutrients from lime and preplant nutrient charge fertilizers in peat-based root media. J. Amer. Soc. Hort. Sci. 121:453460

Bailey, D.A. and T. Bilderback, 1997. Alkalinity control for irrigation water used in nurseries and greenhouses. Hort. Info. Lflt. 558. North Carolina Coop. Ext. Serv.

Biernbaum, J.A. 1992. Root-zone management of greenhouse container-grown crops to control water and fertilizer use. HortTechnology 2:127132.

Bugbee, B. 1995. Nutrient management in recirculating hydroponic culture, p. 15-30. In: Proc. 16th Annu. Conf. on Hydroponics. Hydroponic Soc. Amer., San Ramon, Calif.

Jones, J.B. and V.W. Case. 1990. Sampling, handling, and analyzing plant tissue samples, p. 389-427. In: R.L. Westerman (ed.). Soil testing and plant analysis. Soil Sci. Soc. Amer.

Kent, M.W. and D.W. Reed. 1996. Nitrogen nutrition of New Guinea impatiens 'Barbados' and Spathiphyllum 'Petite' in a subirrigation system. J. Amer. Soc. Hort. Sci. 121:816-819.

McAvoy, R.J. 1994. Nitrate nitrogen movement through the soil profile beneath a containerized greenhouse crop irrigated with two leaching fractions and two wetting agent levels. J. Amer. Soc. Hort. Sci. 119:446-451.

Mills, H.A. and J.B. Jones. 1996. Plant analysis handbook II. A practical sampling, preparation, analysis, and interpretation guide. MicroMacro Publishing, Athens, Ga.

Molitor, H.D. 1990. The European perspective with emphasis on subirrigation and recirculation of water and nutrients. Acta Hort. 272:165-173.

Vavrina, C.S. 1996. Seasonal differences occur in transplants too. Florida Vegetable Transplant Growers News 7(2):1-2.

Warncke, D.D. and D.M. Krauskopf. 1983. Greenhouse growth media: Testing and nutrition guidelines. Michigan State Univ. Coop. Ext. Serv. Bul. E-1763.

Wright, R.D. 1986. The pour-through nutrient extraction procedure. HortScience 21:227-229.

Yeager, T.H., R.D. Wright, and S.S. Donahue. 1983. Comparison of pour-through and saturated pine bark extract, N, P, K, and $\mathrm{pH}$ levels. J. Amer. Soc. Hort. Sci. 108:112-114. 